The Brock Review Volume 11 No. 2 (2011)

(C) Brock University

\title{
Re-imagining the Los Angeles River
}

John Peterson

\begin{abstract}
This essay uses my students' visit to the Los Angeles River and their written reflections as a narrative context for examining literary and filmic representations of the LA River. My larger goal is to illustrate the connection between these representations and the Los Angeles River's various physical transformations and, in so doing, to underscore the relationship between a site's storytelling traditions and its ecological degradation and/or preservation.
\end{abstract}

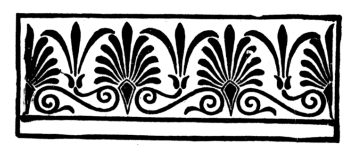

It is a gray Saturday morning in the San Fernando Valley and I am standing along the concrete banks of the Los Angeles River with twenty-five students from my "Urban Nature Writing" class at Pepperdine University. Crouching along the river's edge, they study its glistening, polluted currents with a mixture of curiosity and wariness. Animated conversations and sudden eruptions of laughter mix with the sound of flowing water. With its earthen bottom and concrete banks, this stretch of the river reminds students that our tendency to conceptualize nature and the city as separate realms is but an illusory division. Today is an opportunity for them to explore the nonhuman features of this urban landscape and to envision Los Angeles not as a place in which nature is absent, but as a location in which we transform nature in ways that are destructive and generative towards non-human and human communities. ${ }^{1}$ Our tendency to ignore this ecological vision of Los Angeles has resulted in a host of problems for the city and its residents. As Jennifer Price writes, "In LA, it is so inarguably evident that whether you acknowledge your connections or not, they of course remain operable. Go ahead and ignore your topography, your climate, your hydrology. The air will darken, the mountains will slide into houses, and the lost river will gather toxics and trash."2

Our project in this course has been to consider the role that reading and writing play in reinforcing or diminishing these connections. We begin the course by reading a classic work of American nature writing, Edward Abbey's Desert Solitaire. During our analysis of Abbey's text, we discuss whether or not nature writing such as Desert Solitaire brings "us into a reawakened awareness" 3 of the natural order, or whether it diminishes this awareness through its conception of 
nature as a domain apart from the village, town, or city. For many contemporary readers, the vast majority of whom live within or nearby urban centers, this dichotomy between nature and the city reduces Abbey's text, and much nature writing, to a form of adventure narrative whose counterculture spirit is provocative, but ultimately detached from their daily lives. After reading Desert Solitaire, we transition into more recent examples of American nature writing such as Charles Siebert's Wickerby and Lisa Couturier's The Hopes of Snakes, two works that contrast with Abbey's text through their exploration of the non-human features of their respective cities. As Couturier writes: "A glossy ibis gliding into the lake in Central Park? Peregrine falcons hunting over the East River? Black racers and box turtles moving across Brooklyn? This is disequilibrium. The sense of getting bucked." The "disequilibrium" that Couturier describes illustrates the degree to which we tend to think of nature and the city as separate realms; one of my goals in assigning urban nature texts such as Couturier's book has been to evoke in my students a similar state of "disequilibrium."

The students enrolled in this course are a diverse group of undergraduates who range from sophomores to seniors and business to biology majors, yet on the first day of class they are united by two things: the need to fulfill their upper division literature requirement and the tendency to slip into a romantic vision of nature as untouched wilderness, a perspective that also characterizes much of the American nature writing tradition. The purpose of this course is to challenge the nature/city binary that supports this perspective. By assigning literature that deconstructs the division between nature and the city, students gradually come to recognize that they are never outside of nature. From this vantage point, they can better see the contradictions in practicing a heightened state of environmental responsibility when they visit a national park and a diminished state of environmental awareness in their day-to-day activities. Our visit to the Los Angeles River graphically illustrates the fact that this awareness has dramatic implications for the well being of the urban landscapes many of us inhabit.

Today's visit is not only a physical exploration of the river, it is also an imaginative interaction with this waterway. In an effort to deepen this imaginative exchange, I offer my students the opportunity to use their river tour as a narrative context for their upcoming essays on Siebert and Couturier's books. I encourage them to imaginatively write their papers as they are exploring the river, to be attentive to the connections between text and place, as well as cognizant of the sensory details that offer a context for examining the river more fully. My hope is that the ethical questions and insights discussed during our readings will achieve greater staying power as a result of students situating these concepts within their written observations about the river. Underlying this hope is a 
belief that I reiterate countless times over the course of the semester: reading and writing shape our relationship to place. Nowhere is this more evident than the Los Angeles River.

The written and filmic representations of the river since Father Juan Crespi's first description of it in 1769 reveal not only wildly different images of this waterway, but also the means by which these representations have played an active role in transforming the river and the relationship of the city's residents to it. Broadly stated, these representations fall into one of two categories: the river as an idealized site well suited for human settlement or the river as a site of conflict between humans and/or non-humans. Yet, my students' descriptions of the river break from both of these traditions. In their words the river appears not as an idealized watercourse to be bought and sold, nor does it function as a setting that symbolizes conflict, but instead as a site for healing the non-human and human communities that inhabit this city. This shift correlates with the literature they have read over the course of the semester as well as the significant activist efforts that have been made on the river's behalf over the past 25 years; hence by positioning my students' writing within the context of the river's historical representations, it becomes clear that our ability to better care for our urban landscapes - particularly those that have suffered extreme environmental degradation-is intimately connected to our ability to re-imagine the meanings and possibilities associated with those landscapes.

The earliest examples of writing about the river describe it in strategic terms that helped promote settlement in the area. Our first written description of the river comes from the journals of Father Juan Crespi, a member of the Portola expedition, which left San Diego on July $14^{\text {th }}, 1769$ with the intention of travelling northward to Monterrey in order to establish a presidio and mission in that area. $^{5}$ Crespi's role in the expedition was "to survey lands suited for mission stations that would eventually connect with the planned new settlement at Monterey" and, in his descriptions of the Los Angeles River and its environs, the political agenda that his writing served is clearly evident. In describing their arrival at the river on August $2^{\text {nd }}$, Crespi writes: "This river flows on down nearly at ground level through a very green, lush, wide-reaching valley of level soil...upon one and the other side of the river...lie very large, very green bottomlands, looking from afar like nothing so much as cornfields." Crespi also describes the wild "grapevines... and very good sized roses" growing in this "lush pleasing spot" before concluding that "Good, better than good, and grand though the previous places have been, to my mind this spot can be given the preference in everything, in soil, water, and trees, for the purpose of becoming in time a very large plenteous mission of Our Lady of the Angels of La Porciuncula." Crespi's use of such terms as "green," "lush," and "plenteous," offers an early 
example of the idealized imagery that would play such an important role in nineteenth-century promotional literature that focused on Los Angeles and Southern California. This colorful diction also characterizes the writing of U.S. Army Lt. Edward Ord., who surveyed the area in both 1849 and 1856, and wrote of the river and its surrounding terrain after his second trip:

Rising the slope... we see the city of Los Angeles. Someone points across the plain to a thin line of green some 15 miles off. Where are the houses? Oh, they are surrounded by trees and vineyards. The little white spot you see above the green is the cupola of the church. By and by we rode between willow hedges, and zanjas... of flowing water went perling along the roads and thro the fields of corn and the long rows of vines, the almond and orange groves. All around us was a refreshing green, so grateful to the eyes and nose after the arid brown and yellow of the hot plains. ${ }^{9}$

Ord's description of the "city" cloaks its human presence behind its greenery. The houses are surrounded by "trees and vineyards," while only a "little white spot" of the church is visible above the trees' canopy. In describing the river itself, Ord refers to the "zanjas," a series of earthen canals that were used to divert water from the LA River to the residents of Los Angeles during much of the nineteenth-century. Hence, human presence is both shrouded and clearly visible in Ord's writing. The local residents he does describe are "tucked behind the hedges" in front of "low huts" that "peeped out," 10 yet they are plainly visible in the transformation of the landscape from marshlands that once teemed with "willow and sycamore, elderberry and grape" to newly planted groves of almonds and oranges that were watered by a river whose hydrology had also been transformed through the construction of the zanjas. This image of Los Angeles as a sparsely populated, yet agriculturally blessed landscape, would prove irresistible to Easterners that began migrating in droves following the "completion of a transcontinental railroad link to Los Angeles in 1876."12 Thus, in both Crespi and Ord's writing the river serves largely as a promotional tool, a device that could be used to further the process of settlement, first in the form of Spanish missionaries and then in the form of transplants seeking a fresh start.

Crespi and Ord's idealistic portrayals of the river serve as forerunners of promotional literature that would become dangerously exaggerated towards the end of the nineteenth-century. Los Angeles River historian Blake Gumprecht recounts these increasingly "fanciful” descriptions:

Many of the new towns and subdivisions never existed except on paper, and unscrupulous promoters, in an effort to persuade outsiders that Southern California was indeed the promised land, presented images of the region's rivers that were always exaggerated and at times fanciful. A subdivision map circulated in Eastern 
cities, for instance, offered docking space on the Los Angeles River. Bird's-eye views from the period typically portrayed the river as a deep, wide, full-flowing waterway - and, if the image was printed in color, the river was bright blue-looking more like the Ohio River as it flows through Pittsburgh or the Mississippi as it passes St. Louis than the intermittent stream it was in fact. A brochure advertising home lots in a subdivision south of Monrovia called Chicago Park, meanwhile, depicted ocean-bound steamers on the mostly dry San Gabriel River. ${ }^{13}$

Gumprecht's analysis underscores the vast discrepancy between the LA River's actual characteristics and its portrayal by "unscrupulous promoters." This fictionalizing of the river marks a crucial step in the process by which many modern-day Angelenos have lost track of their city's central waterway. In describing this collective amnesia, Jennifer Price writes: "The engineers rechristened the river the flood control channel. They decreed it was no longer a river-and to the general public, the concrete channel no longer looked wild enough to count as nature. And this is how LA lost its river-not lost as in no longer had one, because LA actually did, but lost as in could no longer see or find it." "14 However, as Gumprecht's analysis reveals, prior to its physical transformation into a "flood control channel," the river was imaginatively transformed in print into "the Ohio River as it flows through Pittsburgh or the Mississippi as it passes St. Louis." The ecological ramifications of this print transformation would prove disastrous. Lured in part by this promotional literature, the population in Los Angeles skyrocketed from 11,000 to 150,000 between 1880 and 1904, while the surface flow of the LA River was pumped dry in an effort to support the newly arriving masses. ${ }^{15}$ Thus, promotional writing that focused on the river during the eighteenth and nineteenth-centuries functioned as an active participant in its demise. The exaggerated descriptions of the river and its surroundings provided a fictional context for a community that has persistently resisted the ecological realties of its surroundings.

By the beginning of the twentieth-century, the LA River had been drained of its surface flow and reduced for much of the year to an industrial dumping ground; nonetheless, the river continued to reassert itself through periodic flooding of epic proportions. The catastrophic damage caused by this flooding would ultimately result in the federal government's decision to "dig a concrete straitjacket for the river."16 As Gumprecht writes:

The U.S. Army Corps of Engineers program of flood control in Los Angeles County remains the biggest public works project that agency has ever undertaken west of the Mississippi River, and the numbers associated with Los Angeles River projects still sound astonishing. By the time construction was completed, fourteen private contractors in thirty-one separate contracts with the government had moved twenty million cubic yards of earth (roughly 800,000 dump truck loads worth). They mixed 3.5 million barrels of cement, placed 147 million pounds of reinforced 
steel, and set 460,000 tons of stone. ${ }^{17}$

Needless to say, the fifty-one mile concrete channel that is today's Los Angeles River bears little resemblance to the river first encountered by the Portola expedition, and just as its physical appearance has radically changed, so have contemporary representations of it. Today's river is perhaps most familiar to twentieth-century audiences as the setting of the drag race in Grease. In this scene, and in many other films that have been shot in the river, the waterway functions as a setting in which humans and/or non-humans struggle to overcome one another. Unlike Crespi and Ord, whose writing focuses on the river itself, these filmic representations focus instead on the conflict occurring within the river. Thus, like the thousands of commuters who pass over its concrete banks each day without realizing it, audiences watching these films are likely to miss the river's presence and/or its potential significance; hence, a process of interpretive recovery is involved in seeking to understand these representations of the river. A compelling example of this concept can be found in the motorcycle chase scene from the 1991, James Cameron film, Terminator 2: Judgment Day. In this scene we witness Edward Furlong, who plays a young John Connor-the future leader of a human rebellion against an army of machines-fleeing from a T1000 Terminator, played by Robert Patrick, that has been sent back in time by the machines to kill young Connor. Complicating the T1000's mission, are the actions of a T800 Terminator, played by Arnold Schwarzenegger, who has been reprogrammed by the human rebellion and sent back in time to protect Connor. Within this scene, reality and fiction merge as Cameron's use of the river provides a real life context that reflects his film's thematic interest in the destructive applications of technology.

Cameron's use of setting in this scene to reveal a world in which humans are threatened by their own technology culminates when Connor seeks to elude the T1000 by darting his motorbike down a concrete ramp and into the LA River's cement corridor; however, as a river that has been radically transformed through human technology, it fittingly offers no escape from the deadly technology now pursuing Connor. This is made dramatically clear when the T1000 intentionally crashes a big-rig it has hijacked through a bridge and down into the riverbed; Cameron's low-angle shot rains concrete rubble upon the audience and captures the powerlessness of young Connor as he watches the approaching Terminator. In this apocalyptic vision of Huckleberry Finn escaping down the Mississippi, Connor's motorbike sends sheets of water fanning behind it as he speeds past the corpse-like bodies of abandoned cars in a futile effort to outrun the hulking big-rig. The low-angle shots of the T1000 are juxtaposed with the high-angle shots of Schwarzenegger following the chase from above. Dressed in black leather, riding a Harley Davidson, and firing a sawed-off shotgun, 
Schwarzenegger's T800 Terminator seems drawn from a futuristic western as he launches his motorcycle through the air, plunges into the riverbed, and ultimately fires a single shot into the big rig's front left tire that causes it to jackknife and burst into a wall of flames. The scene's closing shot is of the T1000, which is composed of "liquid alloy," emerging unscathed from the flames and reconstituting itself into human form. Thus, the destructive consequences of transforming the river into a vast concrete channel are echoed in Cameron's closing shot by the transformation of water itself into the destructive force of the T1000. Paradoxically then, Terminator 2's bleak portrayal of the river may offer a more ecologically informed depiction of this watercourse than the promotional texts of eighteenth and nineteenth-century writers. At the very least, it seeks to warn its audience against the abuses of technology that are a part of the river's twentieth-century legacy. Whereas directors such as James Cameron have seen the river as a battleground in which opposing forces struggle against one another, my students' perceptions of the river are far less antagonistic.

Their written responses to our river tour reveal a sense of wonder at its existence and the wildlife it continues to support, as well as a sense of optimism that the river might serve not as a divisive presence, but as a site for healing some of the divisions within Los Angeles. Unlike Terminator 2, where the river takes a backseat to the conflict occurring within it, my students' descriptions of the river foreground it as their primary interest. This shift in attention, one that might be easily overlooked, carries great significance: it reminds us that in a city which has lost track of its central waterway, the process of reimagining it begins with simply becoming aware of its presence. As one native Angeleno writes: "I have lived in Los Angeles all my life and I was never aware that there was a river."18 Another student notes: “...I was intrigued—almost shocked—by what seemed to be a vast collection of avian wildlife." 19 These reactions recall the "disequilibrium" that Couturier describes upon first observing "Peregrine falcons hunting over the East River" and "Black racers and box turtles moving across Brooklyn." Couturier's "disequilibrium” serves as the initial step in her reimagining of New York City. Drawing on James Hillman's description of the "Greek word for city, polis," as originating in "a pool of meanings related to water," Couturier writes of New York City and, in particular, its degraded waterways: "We need but remember that the city, the metro-polis means at root a streaming, flowing, thronging Mother. We are her children, and she can nourish our imaginations if we nourish hers." ${ }^{20}$ Couturier's call for an ethos of reciprocity between New Yorkers and their waterways is echoed in one of my student's descriptions of the LA river's pollution and its resiliency: 
...I couldn't help but think that the river itself was almost courageously indifferent. The water was running across the cement with the same vivacity that it must have run over land - we can impose, but not compose, its form...The simultaneous existence of a mutilated shopping cart and the splashing river around it was manically beautiful_-silver smashing into silver, colliding sequins. I don't view Los Angeles as "malicious," I don't think our trash is out to do harm-I just think that we owe the river an apology of sorts - a debt of appreciation and recognition. ${ }^{21}$

Local efforts to repay this "debt of appreciation and recognition" are most clearly visible for my students at the 32-acre Los Angeles State Historic Park-known locally as the "Cornfield." The park lies adjacent to the river in Chinatown - very near where the Portola expedition first crossed the river-and represents a major victory for advocacy groups seeking to transform the river from a site that has traditionally divided communities to a location that unites communities around newly constructed green space. In viewing the park and studying the city's "master plan" for constructing similar sites, as well as transforming the river's concrete channel where feasible, one student writes: "With the plans, the layouts, and the 'master plan,' it appears...there is an actual concentrated effort, and more so than that, it seems to be working. Like a gathering storm, people and promises are rallying together." 22 Hence, my students' writing about the river departs from much of this waterway's historical representations. In their writing we do not encounter an idealized watercourse to be bought and sold, nor do we find a setting that symbolizes conflict, but instead a site for healing the non-human and human communities that inhabit this urban landscape.

What happens when these shifts in perception enter into our descriptions of place and begin to reshape the imaginative traditions associated with these places? In his memoir, The Way to Rainy Mountain, N. Scott Momaday writes:

Once in his life a man ought to concentrate his mind upon the remembered earth, I believe. He ought to give himself up to a particular landscape in his experience, to look at it from as many angles as he can, to wonder about it, to dwell upon it. He ought to imagine that he touches it with his hands at every season and listens to the sounds that are made upon it. He ought to imagine the creatures there and all the faintest motions of the wind. He ought to recollect the glare of noon and all the colors of dawn and dusk. ${ }^{23}$

For Momaday, this imaginative process is not a passive act, but one which enables him to "take possession" 24 of a more fully developed, ethical relationship to place. The need to re-imagine our understanding of place is perhaps most evident within our urban landscapes. In locations such as the Los Angeles River, where a history of physical degradation has been compounded by the river's written and filmic representations, this imaginative process is fraught with obstacles. Yet, it is the 
enormity of the river's physical and imaginative alteration that also serves as reason for optimism; for, if the river can be imagined out of our consciousness-as it was for much of the twentiethcentury-then it can also be re-imagined in ways that might lead to transformative action on its behalf. This grand ambition-one that is strangely in keeping with a city that has been defined by its grand ambitions - has inspired the work of countless artists and activists over the last twenty-five years who have found in the Los Angeles River a waterway that illustrates the ecological ignorance and promise of the city they live in. My hope has been that like these individuals, my students might "take possession" of a new idea of Los Angeles and its neglected river. Whether this has occurred in any lasting fashion is impossible to say. I have only their words to go by.

\section{Notes}

${ }^{1}$ William Deverell and Greg Hise, eds., Land of Sunshine: An Environmental History of Metropolitan Los Angeles (Pittsburgh: University of Pittsburgh Press, 2005), 4.

${ }^{2}$ Jennifer Price, "Thirteen Ways of Seeing Nature in LA," in Land of Sunsbine: An Environmental History of Metropolitan Los Angeles, ed. William Deverell and Greg Hise (Pittsburgh: University of Pittsburgh Press, 2005), 236.

${ }^{3}$ Edward Abbey, Desert Solitaire (New York: Simon \& Schuster, 1990), 37.

${ }^{4}$ Lisa Couturier, The Hopes of Snakes (Boston: Beacon Press, 2005), xii.

${ }^{5}$ Blake Gumprecht, The Los Angeles River: Its Life, Death, and Possible Rebirth (Baltimore: The Johns Hopkins University Press, 2001), 35.

${ }^{6}$ Alan K Brown, ed., "Introduction," in A Description of Distant Roads: Original Journals of the First Expedition into California, 1769-1770, (San Diego: San Diego State University Press, 2001), 46.

7 Juan Crespi, A Description of Distant Roads, ed. Alan K. Brown, (San Diego: San Diego State University Press, 2001), 337.

8 Ibid, 338-39.

${ }^{9}$ Edward Ord, The City of the Angels and The City of the Saints, (San Marino: The Huntington Library, 1978), 9.

10 Ibid, 9 .

${ }^{11}$ Gumprecht, 2.

12 Ibid, 83.

${ }^{13}$ Ibid, 83-84.

14 Price, 229.

${ }^{15}$ Gumprecht, 83.

16 Price, 229.

17 Gumprecht, 226.

${ }^{18}$ Jessica Tisdale, journal response, April 2009.

${ }^{19}$ Ethan Hamilton, journal response, April 2009.

${ }^{20}$ Couturier, 3.

${ }^{20}$ Laura Laplaca, journal response, April 2009.

21 Thor Anderson, journal response, April 2009.

${ }^{23}$ N. Scott Momaday, The Way to Rainy Mountain, 83.

${ }^{24}$ N. Scott Momaday, "The Man Made of Words," 85.

\section{Bibliography}

Abbey, Edward. Desert Solitaire. New York: Simon \& Schuster, 1990. 
Brown, Alan K., ed and trans. A Description of Distant Roads: Original Journals of the First Expedition into California, 1769-1770. San Diego: San Diego State University Press, 2001.

Couturier, Lisa. The Hopes of Snakes. Boston: Beacon Press, 2005.

Crespi, Juan. A Description of Distant Roads. Edited and Translated by Alan K. Brown. San Diego: San Diego State University Press, 2001.

Deverell, William and Greg Hise, eds. Land of Sunshine: An Environmental History of Metropolitan Los Angeles. Pittsburgh: University of Pittsburgh Press, 2005.

Gumprecht, Blake. The Los Angeles River: Its Life, Death, and Possible Rebirth. Baltimore: The Johns Hopkins University Press, 2001.

Momaday, N. Scott. "The Man Made of Words." In Nothing But the Truth: An Anthology of Native American Literature, edited by John L. Purdy and James Ruppert, 82-93. New Jersey: Prentice-Hall Inc., 2001.

---. The Way to Rainy Mountain. Albuquerque: University of New Mexico Press, 1969.

Ord, Edward. The City of the Angels and The City of the Saints. San Marino: The Huntington Library, 1978.

Price, Jennifer. “Thirteen Ways of Seeing Nature in LA.” In Land of Sunshine: An Environmental History of Metropolitan Los Angeles, edited by William Deverell and Greg Hise, 200-245.

Pittsburgh: University of Pittsburgh Press, 2005.

Siebert, Charles. Wickerby: An Urban Pastoral. New York: Three Rivers Press, 1998. 